\title{
Overcoming alienation in Africanising theological education
}

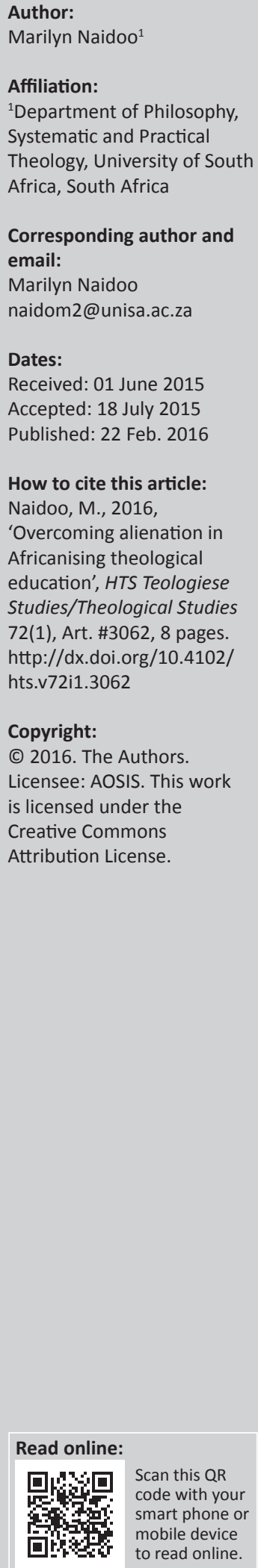

Africanisation refers to a renewed focus on Africa, a reclaiming of what has been taken from Africa, and forms part of a post-colonialist and an anti-racist discourse. Africanising the curriculum involves developing scholarship and research established in African intellectual traditions. The idea is that this education will produce people who are not alienated from their communities and are sensitive to the challenges facing Africa. However, the idea of Africanisation is highly contested and may evoke a false or at least a superficial sense of 'belonging,' further marginalisation, or it may emphasise relevance. This article discusses the possibility of Africanisation and takes further the argument of Graham Duncan of how Africans can reclaim their voices in the space of theological education. It unpacks the idea of Africanisation within higher education in general, examining the rationale behind the calls for Africanisation, followed by a discussion on the implications of Africanisation for theological education.

\section{Introduction}

Theological education in 21st century Africa has to operate in both a post-colonial and globalising context. However, it is still to a large extent confronted by the legacy of colonial forms of theological education that remained in place decades after political decolonisation. In his article "Theological Education Mission birth - African Renaissance' Graham Duncan (2000:23) examined the problematic issue of Western scholarship as the authority in African theological education, 'that though there have been calls for transformation, these have not been heeded'. Duncan notes the cultural hierarchy, quoting Fanon (2000:24), which 'denotes a scaled inferiority in which the indigenous culture is devalued by the colonial settlers, whose culture is itself understood to be inferior to the colonial centre'. This 'absence of Europe' nostalgia in the theological scene no longer commands widespread assent (Fanon 2000:24), since there are relevant viable alternatives within the context. Duncan states that 'any new methodology will need to liberate from the certainties of western theology' (Duncan 2000:25) and continues to quote Mbiti (1976):

Freedom from theological inhibitions also means the freedom to make mistakes. The theologians of the new Christendom must be free to hatch their own heresies and theological errors, for often [it is] in response to heresies and errors that sound theological orthodoxy is generated. (p. 16)

Duncan (2000:27-28) makes it clear that within theological education there is a need not only for change of the forms and content of the curriculum, but also for a focus on the poor in society. Contextual theology is only adequate when it engages with the actual context (Duncan 2000:27-28). As Abraham (1997) states:

We reject as irrelevant the type of theology that is divorced from action. We are prepared for a radical break in epistemology which makes commitment as the first act of theology and engages in critical reflection on the praxis of reality in the third world. (p. 148)

Duncan has made the call for an African Renaissance together with advocates, such as Boesak (2005), Botman (2008), Maluleke (1998) and Wa Thiong'o (1993), who state that much of what has been taken for theological education in Africa is in fact not African but rather a reflection of Europe in Africa. The inference here is the distorted view that Africans possess little or no indigenous knowledge of value that can be utilised in theological education, where the English language is sacralised, and the internalisation of bourgeois European values is seen as the index of progress (Sefa Dei 2013). This situation is compounded by globalisation, which has corrupted African culture through its progressive technological changes in communication, political and economic power, knowledge and skills as well as cultural values, systems and practices (Nicolaides 2012). Shizha (2011:2) notes that globalisation promotes the epistemological and ontological realities of the most powerful in the world. In so doing globalisation has, as Maweu (2011:36) observes, catalysed the colonisation of African ways of knowing. 
The dominant curriculum continues to be a source of alienation. African intellectual representations are inconsistent with the lived experiences of the majority of African people. Often, the curriculum does not speak to the experiences of students, because the curriculum does not reflect the philosophical, social and technological realities of their environment (Lebakeng, Phalane \& Dalindjebo 2006). The colonisation process has brought about 'colonized minds and education systems' (Andraos 2012:6), which is a very involved form of power, more difficult to identify, resist and transform. The work of uncovering dominant Western paradigms of knowledge is not new. However, as Andraos states, not enough attention is given to epistemic decolonisation that attempts to unveil the 'geo-political location of theology, secular philosophy and scientific reason and simultaneously affirming the modes and principles of knowledge that have been denied the rhetoric of civilization, progress, development and market democracy' (quoting Mignolo 2007:463, in Andraos 2012:7). The dominant Eurocentric universality claim must continue to be challenged and dismantled in order to make room for other theological traditions to become included as partners in an authentic and mutual dialogue.

To transcend the Eurocentrism of theological education and include voices and sources from other cultural perspectives, Maluleke's call to Africanise theological education 'explicitly illustrates one of the ways in which Africa, as a hermeneutical trope, frames the possibility of discourse on identity, culture and theology' (Antonio 2006:19). Maluleke underlines the inability of traditional approaches to address the spiritual needs of the African community and argues for an Africanisation of theological education characterised by 'a bias towards African issues, a change of content, method, objective and vision' (Maluleke 1998:9). Africanising the curriculum involves developing scholarship and research established in African intellectual traditions (Maile 2011:111). In this way local knowledge and wisdom is valued with multiple theoretical frameworks instead of classical theoretical texts, which can pressure students to use Western ideas to interpret their own experience and cultural contexts. Africanisation seeks to dispel, exorcise and displace Western paradigms of African identity through rethinking the entire ideological church apparatus of theological education from the standpoint of African questions and answers (Maluleke 2006:72-73).

The debate on Africanisation has developed because of the larger discourse on the transformation of higher education; to undo decades of injustice caused by apartheid. The transformation of universities involves major academic, intellectual and philosophical arguments about whose knowledge to teach, learn and research. These discourses are made up of issues around curriculum reform, internationalisation, the role of higher education in a newly democratic country and the issue of Africanisation (Letsekha 2013:1). With regard to the local curriculum, there is a renewed focus on indigenous knowledge and an African community competing in a global society (Williams \& Gardner 2012:215).

\section{Botha (2007) quoting Coetzee (1999)}

contends that the Africanising of universities encompasses three dimensions. The first dimension refers to the academic decolonisation of Africa, thereby confirming the connectedness of African universities to Africa and promoting a unique African philosophy and culture at these institutions. He presents the second dimension as the relevance of these institutions to Africa, in that they ought to address the needs and expectations of developing, mainly Third World countries in Africa. Thirdly, the legitimacy of universities in Africa is measured in terms of their focus on the needs, circumstances and aspirations of Africans. (p. 207)

Examples of theological institutions seeking to Africanise their theology would be the University of South Africa, which is 'proudly African in the service of humanity' (UNISA online, n.d.). This wording refers to an attempt to be 'relevant in the communities in which they are serving and working by trying to ensure that they are relevant to the African context... by ensuring that the lens through which they approach the design of curricula is an African lens' (Williams \& Gardner 2012:215). The University of KwaZulu-Natal encapsulates its vision as 'the premier university of African Scholarship' (Karlsson \& Pillay 2011:235), evidenced in the Ujamaa Centre (for biblical and community development and research). The work involves an interface between socially engaged biblical and theological scholars and local communities of the poor, working-class and marginalised. The centre works with 'struggle' as a key socio-theological concept and 'wrestles' with the biblical text towards individual and social transformation (http://ujamaa.ukzn.ac.za).

This issue of Africanisation is not without contestation, with authors offering differing viewpoints on what the process is and what it should entail. For example, Horsthemke (2004b) states that the concept of Africanisation lacks clarity in terms of meaning and content, especially in regards to who has the 'right to be African', and that it may be insufficient as a theoretical framework for conceptualising the change needed (Horsthemke 2009). Maile (2011:111) suggests that Africanisation is seen to be equated with political propaganda bent on racial cleansing or, worse, opposition from indigenous knowledge forums that state that indigenous knowledge is inaccessible and is not recorded. As Maluleke (2010:371) maintains, current discourse on Africanisation is conducted in the midst of several 'historical, ideological, theological and contemporary landmines'.

In this article I take further the argument of Graham Duncan and his concern for a relevant theological education, which was an issue at the forefront of his academic writing. To do this I will unpack the idea of Africanisation within higher education generally and examine the rationale behind the calls for Africanisation, followed by a discussion on the implications of Africanisation for theological education. This discussion is important, as within our political history in 
South Africa, theological education, like everything else, has been racialised and informed by different ideologies that either supported or opposed apartheid. Theological education in South Africa reflects the deep divides of the context within which it is situated - South Africa itself is politically, economically and culturally a contested space and theological education is equally complex and heterogeneous. This complexity within theological praxis calls for an approach that takes on a diversity of perspectives of cultural, public and Christian life, with Africanisation representing one of these 'other' perspectives.

\section{Differing notions of Africanisation}

To begin with, there are many definitions of Africanisation that seem similar, such as the need to seek commonalities; affirm African culture, traditions and value systems; and foster an understanding of African consciousness (Horsthemke 2004b). Makgoba (1997:199) for example, emphasises culture and identity, noting that Africanisation is a process of inclusion that stresses the importance of affirming African cultures and identities in a world community. Other scholars emphasise a collectivism, an ubuntu (Higgs 2003), and some others focus on the humanistic ideals of justice and human rights (Parker 2003). Louw (2010:43) views Africanisation as a way of transcending individual identities, seeking commonality, as well as a way of recognising and embracing our 'otherness'. This will allow for people to connect with the broader African experience and help establish curricula that will bring people together (Louw 2010:43). Wiredu (2005:7) conceives of Africanisation as being attentive to communalism, social justice and deliberation as well as blending Western and African methodologies.

Ramose (1998), on the other hand, states that Africanisation embraces the understanding that the 'African experience' is not only the 'foundation' of all forms of knowledge, but also the 'source' for the construction of that knowledge. Ramose (1998) goes on to assert that while the 'African experience' is non-transferable it is indeed communicable, but only by the African. This conceptualisation of Africanisation has been challenged by Horsthemke (2004a) for its failure to do justice to the issues of diversity. Ramose's version of

Africanisation appears to warrant a need to define who or what is African, a process that can easily lead to marginalisation and exclusion, which proponents of Africanisation are trying to avoid. (Letsekha 2013:2)

\section{According to Botha (2007):}

Africanisation is synthesised by Vorster (1995:9) as an appeal, in the first place to Africans and, in the second place, to Europeans and non-Africans. The first appeal relates to Africans upholding African aspirations; descent; cultural heritage; own ideas, rights, interests and African ideals; self-concept and own rationality in the intercultural context. The second appeal relates to non-Africans to respect and accommodate Africans' efforts to manifest the first. (p. 205)

Accordingly, it is the African who is and must be the primary and principle communicator of the African experience.
Africanisation is a conscious and deliberate assertion of nothing more or less than the right to be African.

Thus a key issue in discussing Africanisation is the question of who is the African, as an increasing number of people in South Africa, of differing races, perceive themselves as being African. This has much to do with the question of whether such an identity could indeed be identified at all (Goduka 1999; Makgoba 1997). Some voices have answered in the affirmative, such as Le Roux (2001) and Makgoba and Seepe (2004). Ramose (2003:114-116) argues that the term Africa(n) is contestable on at least two grounds. One is that the name is not conferred by the indigenous people of Africa on themselves. Another is that the name Africa(n) does not by definition refer to the particular histories of the indigenous peoples inhabiting various parts of the continent from time immemorial. In other words, the term is geographically significant but historically its meaning is questionable from the point of view of indigenous African peoples.

The question of cultural identity in an African context directs attention at what meaning is attached to the adjective African. LeBeau and Gordon (2002:218) maintain that the African Renaissance universalises African identities toward a single African culture, whereas Nehusi's (2004) definition of an African has clear reference to the basis of identity as having to do with skin colour. This raises a serious ontological issue for theological education on the African continent: do the prospects of the inclusion of indigenous African epistemologies in theological education in Africa include a place for all races and cultural groups? At the same time, Appiah (1994:2) is critical of all assertions of a united, homogeneous African voice, African identity, and what he calls radical pan-Africanism, declaring that Africa is like, '... my father's house in which there are many mansions... meaning that there are, and should be, many and various ways of being African'. Other African philosophers, for example Hountondji (1996), regard an intellectual product as African simply because it is produced or promoted by Africans. Higgs (2015:40) states that an African is a person who shares with others a common geographical origin as well as ownership of and spiritual attachment to the ancestral land known as the continent of Africa; therefore African includes members of all races and cultural groups.

\section{Challenges with Africanisation}

Botha (2007) states that:

There are opposing viewpoints to Africanisation of higher education, some based on the argument that there has apparently never been a need to 'Indianise' universities in that country, or to 'Anglicise' the University of Oxford. Moulder (1995:7) recognises that these are absurd ideas, but that the absurdity of 'Africanising' South African universities makes sense, as it is underpinned by the previous fundamental injustices in South African society. He identifies several components of Africanising universities, these being changing the composition of academic, student and administrator bodies, changing the curriculum ('the whole way in which teaching and learning are organised') and changing the criteria that determine what is excellent research (1995:8). (p. 206) 
However, according to Letsekha (2013:8), while some institutions of higher learning have made strides in contextualising their pedagogical structures, curricula still exist that privilege Western ways of knowing despite the space allowed by the new constitution for retooling educational discourse.

In South Africa the task of creating a curriculum that is fit for the post-1994 era is to open the space for 'diverse ontological narratives', not to insist on 'erasure or a Euro-ethnic mono-discourse' (Adesina 2006:144). Van Wyk and Higgs (2005:2) agree that 'much has been written about the university, and such work seems to be dominated by Western ideas'. They go on to say that when non-Western educational traditions are examined, this usually happens through a Western lens, which results in a distortion of understanding these traditions. To enhance authenticity, much care is needed in the process of Africanising; this is also necessary to prevent further marginalisation (Van Wyk \& Higgs 2011:177). A University of Leuven study found that African universities had been effective in Africanising their personnel but not their curricular or pedagogical structure to any real extent because of insufficient resources (Crossman \& Devisch 1999). According to Nyamnjoh (2004:160) higher education on the continent has been affected by an internalised sense of inadequacy in Africans, together with the mission of devaluation of African creativity, agency and value systems.

Another issue to consider in this debate is the one of internationalisation, which states the more a university chooses to Africanise the less it can internationalise, and vice versa (Botha 2010:201). Neale-Shutte and Fourie (2006:121) maintain that in order to be participants in internationalisation, African universities need to create their own identities; 'if you do not know who you are then you do not have much to offer your international counterpart.' It is only when 'one has a deep understanding of experiences that one is able to conquer knowledge and concepts that are not part of that experience' (Dowling \& Seepe 2004:196).

This framework would help develop a critical stance towards ideas and concepts from the West (Alatas 2009), as well as the ability to raise original problems, devise original analytical methods and use indigenous resources, for example, indigenous languages (Wa Thiong'o 1987; Wiredu 1995). Prah (1998) argued that the absence of African languages has been the 'missing link' in African development, resulting from the preoccupation with the benchmark of using English as the Western standard. Ramose advices that rather than maintaining and applying given academic and educational standards, we need to continually create and redefine them (1997), and this cannot be done in abstracto. Africanisation is essentially part of continually creating and redefining educational standards within appropriate contexts of relevance.

With Africanisation the use and revalidation of indigenous knowledge systems (IKS) is seen as the solution to dependency. According to Lebakeng et al. (2006:76) to reverse epistemicide is to place IKS 'on the same level of parity with other epistemological systems in an effort to achieve formal and substantive equality'. However, again it is the issue of whose knowledge is at play and it may intersect in a troublesome way with identity politics (Horsthemke 2009). If 'African' is equated with 'indigenous ethnic identity' then there is no place for those whose African identity has other grounds. According to Pityana (2012) one needs to avoid a reliance on IKS because this tends to lead to IKS being characterised as an exotic subject or discipline. Crossman (2004) argues that it does not help to racialise or ethnicise concepts of knowledge and one must therefore find other criteria and definitions for local or regionally shared knowledge or practices. According to Letsekha (2013:12) instead of indigeneity the crux of the issue may better be evoked by the use of the term endogenous knowledge; this collective term describes a set of discourses that has emerged in opposition to Western educational discourse. Letsekha (2013:13) clarifies the difference between the terms indigenous and endogenous in the field of botany, where indigenous can be used to refer to a species being native to a particular topography whilst endogenous refers to a plant's capacity to develop on the basis of its own resources or by growing from within. The 'topographical definition portrays the subject as static whereas the endogenous definition allows for a more organic and dynamic understanding' (Crossman 2004:324). According to Ake (1979) endogeneity is appropriate, as even though the principles of science are universal, its growth points, applications and the particular problems it solves are contingent on the historic circumstances.

Rather than being viewed as attempts to delink from metropolitan control, these should be viewed as a contribution of non-Western systems of thought to theories (Alatas 2009:143). These discourses are informed by local historical experiences and cultural practices in the same way as Western discourses. This commitment to endogeneity involves not only distinct epistemological insights from the locale but also 'taking the locale and its ontological locations seriously as the basis of knowledge production' (Adesina 2006:136). Applied to universities it refers to the development of African universities and their processes of production along lines consistent with the constantly changing cultural and material situation of the communities and learners they serve (Letsekha 2013:13).

\section{The possibility of Africanising theological education}

There has been much discussion about the need for reconstructing theological education in the African context, as the overall character of much of theological education is overwhelmingly Western and Eurocentric. Whether the theology taught in institutions is Christian dogmatics or constructive theologies, it invariably focuses on Euro-Western formulations of faith and philosophical thought. The very language of discourse that has developed is inherently racialised as white and normative. Contemporary voices call on theology to become more contextual, practical or relevant, 
rather than being a highly theoretical discipline, with a growing distance between the academy and the local church. Africanisation seeks to dispel, exorcise and displace Western paradigms of African identity through 'rethinking the entire ideological church apparatus of theological education from the standpoint of African questions and answers' (Antonio 2006:19). It is for this reason that Africanisation has become a key problem in defining the content and task of theological education. Underlining the role of education as a colonising technology, Antonio states (2006:19) that Africanisation suggests:

\begin{abstract}
...why education was such a critical site of contestation during and after colonial rule: it is within education that categories of thought were formally defined and the conditions for the articulation of colonised subjects were laid down and strategies for colonised minds were deployed. (p. 19)
\end{abstract}

At the same time theological educators remain largely unconvinced of Africanisation. The need for Africanisation is not commonly felt or shared. Africanisation is seen as too complex, controversial and ideological, even though every position within theology points to a particular ideology. Critics point out that Africa is so divergent that it is difficult to offer a monolithic definition of who an African is or to define Africanisation. In considering Africanising theological education, one has to consider Africa's place and status in the world. Africa's emergence as a major centre of world Christianity is hostage to its marginalisation in the new global order - academic marginalisation being a corollary of economic insignificance (Gatwa 2003:204). As Maluleke (2010:372) has suggested, the very idea that Christianity could be Africanised has been viewed as suspect, that Africanisation can mean a lowering of universal 'Christian standards' in order to fit in with some local 'African standards'.

Africanisation remains a critical engagement with both Christian theology and its context whilst at the same time attempting to chart the path of liberation (Maluleke 2006:70). Theology in this context has a unique role to play in acknowledging, valorising, interpreting and enhancing the agency of African Christians (Maluleke 2000) in their daily struggles against cultural, religious and economic forces of death that seek to marginalise them. More support is needed for a contextual theology, and not one that 'obscures rather than reveals' (Mosala 1985:103), or for a liberationist theology that recognises the social positioning of those doing theology: a theology that is relevant to oppression and exclusion from a non-Western perspective. It is important to note that Africanisation is not merely a form of cultural romanticism or a form of cultural nationalism but will need to involve a critical appraisal of African traditions and cultures against the criteria of their liberational import (Maluleke 2006:73).

Since Eurocentric approaches are dominant in the field of theology influencing both the content and the way knowledge is communicated, a strategy within Africanisation would be to explore the epistemic potential of inter-cultural learning, that is respectful of and engage voices and sources from other cultural perspectives (Andraos 2012:7). According to Andraos (2012:7) it begins by 'acknowledging that the cultural, religious and theological knowledge represented in the classroom are not equally valued'. Mignolo's terms, persons who 'come from different places' and 'think from different locations', that is, from different worldviews, are not interacting mutually (Mignolo 2007:490-492). There is a hierarchy of systems and sources of knowledge, with the Western perspective at the top of the pyramid, which is consistently affirmed in subtle ways as universal. 'In order to uncover the perverse logic - that Fanon pointed out-underlying the philosophical conundrum of modernity / coloniality and the political and economic structure of imperialism/colonialism', notes Mignolo, 'we must consider how to decolonize the 'mind' . . . and the 'imaginary' . . . that is knowledge and being' (Mignolo 2007:450). The approach advanced by Mignolo (2007) for decolonising knowledge is described in terms of 'delinking':

De-linking then shall be understood as a de-colonial epistemic shift leading to other-universality, that is, to pluri-versality as a universal project. . . . [Delinking] leads to de-colonial epistemic shift and brings to the foreground other epistemologies, other principles of knowledge and understanding and, consequently, other economy, other politics, other ethics. 'New inter-cultural communication' should be interpreted as new interepistemic communication. (p. 453)

Andraos (2012:10) suggests that through intercultural learning students can bring different knowledge from their respective traditions. For example, in 'Fighting the Elephant in the Room: Ethical Reflections on White Privilege and Other Systems of Advantage in the Teaching of Religion' authors Hill, Harris and Martinez-Vazquez (Hill et al. 2009:4) offer insightful pedagogical analysis and a strategy for nurturing a liberating education that takes the issues of social justice seriously. Their insightful pedagogical model involves (1) engaging students where they are, (2) helping them identify their identities and social locations and (3) helping them acknowledge the reality of injustice and oppression, understood as 'sanctioning and nurturing of systems of inequality that are woven throughout social institutions and embedded within individual consciousness' (Hill et al. 2009:8). In contrast, pedagogical strategies rooted in the antiracist discourses place emphasis on critical thinking as the foundation for new meaning construction, self-discovery and self-creation against the legacies of prejudice and alienation. Work needs to be done to engage with the psychosocial effects of colonization, the internalized oppression and superiority that is still present with students and even educators. Through exploration and reflection, students are challenged to question the taken-for-granted notion of their rootedness in a culture or a nation. Andraos (2012) maintains:

From a de-colonial perspective, awakening and engaging seriously the thinking of students who bring different knowledge from their respective traditions and the experience and wisdom of their peoples and communities is crucial. This way of constructing knowledge shifts the focus from abstract thinking that values individualism and ideas from dominant 
theoretical frameworks to a way of learning that is rooted in cultural experiences in conversation with multiple theoretical frameworks. (p. 12)

In the same vein, Higgs (2015) states that change will entail countering the colonisation of the African mind by transformative educational discourses: the asking of critical questions about the knowledge included in theological education and the languages spoken and used as the medium of instruction. These discourses will also ask which ways of knowing validate and promote local knowledge and which ones ignore and invalidate local knowledge, and why. Also important is how indigenous African epistemologies are used. These can be tapped as a foundational resource for theological education in terms of sharpening teaching methods, relevant research methodologies and practices. Examples include the discourse of community in Africa, also referred to as communalism, and the African ethic of Ubuntu (Higgs 2015). Duncan (2000:26) agrees, stating that 'reality needs to be redefined in terms of community rather than individualism', emphasising the necessity of inter-relatedness and interdependence. These epistemologies respect diversity, acknowledge lived experience and pay attention to the present-day issues of concerns to Africans.

Thus the strengths and insights of African ideas can be recognised, studied and used to enhance and advance theological approaches. This will provide for the construction of empowering knowledge that will enable communities in Africa to establish their own African identity in theological education. This learning creates opportunities for delinking from dominant ways of thinking; however it must not be limited to one course but must become mainstreamed within theological curriculum and the learning environment. In this way, the supremacy of the Eurocentric universality claim can be taken down so as to make space for other theological traditions to become genuinely included as equal partners in joint dialogue.

At the same time there should also be a discussion about maintaining the current theological 'canon' and about widening the dialogue to include other voices. This very critical issue is much deeper than simply adding black scholars to the syllabi or black and African theology to the curricula (Maluleke 2006:69). It has significant implications for the shape of theological discourse and the redefining of who should be the 'gatekeeper' and who should be involved in the 'decolonialization' of curricula (Andraos 2012).

Within our South African context Christians can no longer afford to ignore the issue of Africanisation in their congregations and ministerial formation. The work of Ntsimane (2010) from a Lutheran perspective, Kritzinger advocating for an African Reformed ministerial formation (2012) and Richardson and Leleki (2010) from a Methodist perspective show that denominations are re-imagining their ministerial formation. There is a need to work towards becoming part of the collective, towards a new nation, a common African-ness. As Gathogo points out
(2007:109), Ubuntu ('personhood' or 'humanness') entails among other things the notion of hospitality. Kritzinger (2012) suggests that what is sorely needed is for us to affirm our connectedness and solidarity with all people around us:

What we need as an underlying ethos for everything we do in ministerial formation, is a spirituality of inclusion, reaching out to people who are different, thinking them into our lives as part of our world view ... (p. 40)

The question has to be asked anew (Louw \& Mouton 2009): 'What does it mean to practise theology in an African context beyond the borders of a European and North American paradigm?' To contribute to international discourse we first need to understand what our own African stance entails; as Maluleke asks, 'Do we know ourselves theologically?' (2006:63). Context is crucially important as it influences the way we theologise. The challenge remains for us to form our own meanings of sustainable theological education for our own time and place. We 'need to drink from our own wells' (Maluleke 1996:3), as location and positionality make a difference. As we know, all things African have to be partial, provisional and contextual. Nevertheless, there is a need to create a greater awareness of the rich heritage of African theology, of the problems facing Christians on the continent and of the creative approaches adopted by African churches in addressing those problems. Hence it will involve a commitment from all critical and transformative theological educators in Africa to have Africa as their focus. Future leaders will also need to be interpreters and mediators between the local and the global, what sociologist Roland Robertson (2003:3) describes as 'glocal' which 'means the simultaneity - the copresence - of both universalizing and particularizing tendencies'. This will require a multiperspectival approach with appropriate curricular modifications in ministerial and missional modes.

\section{Conclusion}

Africanisation of theological education is a clear ideological position and process characterised by new styles of method and content and will continue to be controversial in the sense that it involves a continuing critique of 'the massive diversity in Africa and the multiplicity of ways of being African' (Duncan 2000:29) in favour of the liberation of all Africans. This concept of Africanisation has been dynamic in the past and it can reasonably be assumed that it is currently still dynamic. However, a plurality of ideas needs to inform the process.

This article has briefly summarised the key arguments within Africanisation and shown how this epistemic decolonisation could be possible by endogeneity, taking the locale and its ontological locations seriously as the basis of knowledge production. This can be further supported by attempts to delink from metropolitan control using liberatory education methods, which will make space for a variety of voices to be heard in the theological education space. Graham Duncan 
(2000) will support this, with his commitment to the church on the edge of the margins where the majority of people are:

Perhaps we need to experience a little uncertainty in our theological education (as we constantly do in our churches) to make it truly African...Do we want to project the image of the successful, triumphalistic church or must that type of imagery give way to that of a vulnerable servant community? Perhaps a dose of insecurity laced with humility will actually make us more dependent on God and more useful to the communities we seek to serve. (p. 39)

\section{Acknowledgements Competing interests}

The author declares that she has no financial or personal relationships that may have inappropriately influenced her in writing this article.

\section{References}

Abraham, K.C., 1997, 'A response', in Pobee (ed.), Towards viable theological education: Ecumenical, imperative, catalyst of renewal, World Council of Churches, Geneva.

Adesina, J.O., 2006, 'Sociology beyond despair: Recovery of nerve, endogeneity, and epistemic intervention', South African Review of Sociology 37(2), 241-259. http:// dx.doi.org/10.1080/21528586.2006.10419157

Ake, C., 1979, Social science as imperialism: A theory of political development, Ibadan University Press, Ibadan.

Alatas, S.F., 2009, The definition and types of alternative discourses, viewed 01 May 2015, from http://www.ios.sinica.edu.tw/cna/download/5b_Alatas_2pdf

Andraos, M.E., 2012, 'Engaging diversity in teaching religion and theology: An intercultural, de-colonial epistemic perspective', Teaching Theology and Religion 15(1), 3-15. http://dx.doi.org/10.1111/j.1467-9647.2011.00755.x

Antonio, E.P., 2006, Inculturation and postcolonial discourse in African theology, Pete Lang, New York, NY, NY.

Appiah, K.A., 1994, In my father's house: Africa in the philosophy of culture, Oxford University Press, New York, NY.

Boesak, A., 2005, The tenderness of conscience: African Renaissance and the spirituality of politics, Wild Goose Publications, Glasgow.

Botha, M.M., 2007, 'Africanising the curriculum: An exploratory study', South African Journal of Higher Education 21(2), 2020-216. http://dx.doi.org/10.4314/sajhe. v21i2.25630

Botha, M.M., 2010, 'Compatibility between internationalizing and Africanizing highe education in South Africa', Journal of Studies in International Education 14(2), 200-213. http://dx.doi.org/10.1177/1028315309357943

Botman, H.R., 2008, 'Good governance - the role of the churches: A South African perspective', viewed 01 May 2015, from http://www.3.gkke.org/fileadmin/files/ publikationer/2008/spier workshop-beitrag.pdf

Coetzee, S.A., 1999, "n Blik op die afrikanisering van universiteite', South African Journal of Education 19(2), 130-139.

Crossman, P., 2004, 'Perceptions of "Africanisation" or "Endogenisation" at African Universities: Issues and Recommendations', in P.T. Zeleza \& A. Olukoshi (eds.) African Universities in the twenty-first century, vol.2, pp. 319-340, CODESRIA, Dakar, Senegal.

Crossman, P. \& Devisch, R., 1999, Endogenisation and African Universities: Initiatives and issues in the quest for plurality in the human sciences. A Report on a Policy-forming Research Project Commissioned by the Flemish University Council (VI.I.R.) with the Support of the Belgian Administration for Development (ABOS). Belgian Administration for Development Co-operation, Brussels.

Dowling, D. \& Seepe, S., 2004, 'Towards a responsive curriculum', in S. Seepe (ed.) Towards an African identity of higher education, pp. 185-189, Vista University, Pretoria.

Duncan, G.A., 2000, 'Theological education: mission birth - African renaissance', Missionalia 28(1), 23-40.

Gathogo, J., 2007, 'Revisiting African hospitality in post-colonial Africa', Missionalia $35(2), 108-320$

Gatwa, T., 2003, 'Theological education in Africa: What prospects for sharing knowledge?', Exchange 32(3), 192-213. http://dx.doi.org/10.1163/157254303X00019

Goduka, I.N., 1999, Affirming unity in diversity in education: healing with Ubuntu, Juta, Cape Town.

Higgs, P., 2003, 'African Philosophy and the transformation of educational discourse in South Africa', Journal of Education 30(1), 5-22.

Higgs P., 2015, 'The African Renaissance and the decolonisation of theological education', in M. Naidoo (ed.), Contested issues in training ministers in South Africa, pp. 42-56, Sun Media, Stellenbosch.
Hill, J.A., Harris, M.L. \& Martinez-Vazquez, H.A., 2009, 'Fighting the elephant in the room: Ethical reflections on white privilege and other systems of advantage in the room: Ethical rellections on white privilege and other systems of advantage in the teaching of religion', Teaching Theology
org/10.1111/j.1467-9647.2008.00471.x

Horsthemke, K., 2004a, “'Indigenous knowledge" - Conceptions and misconceptions', Journal of Education 32, 31-48.

Horsthemke K., 2004b, 'Knowledge, education and the limits of Africanisation, Journal of Philosophy of Education 38(4). http://dx.doi.org/10.1111/j.03098249.2004.00405.x

Horsthemke, K., 2009, 'The South African higher education transformation debate: Culture, identity and "African ways of knowing,"' London Review of Education 7(1) 3-15. http://dx.doi.org/10.1080/14748460802700512

Hountondji, P.J., 1996, African philosophy: Myth and reality, Indiana University Press, Bloomington, IN.

Karlsson, J. \& Pillay, G., 2011, 'Africanising scholarship: The case of UDW, Natal and UKZN postgraduate research (1995-2004)', South African Journal of Higher Education 25(2), 233-251.

Kritzinger, J., 2012, 'Ministerial formation praxis in the uniting reformed church in Southern Africa: In search of inclusion and authenticity,' in M. Naidoo (ed.), Between the real and the ideal: Ministerial formation in South African Churches, pp. 33-47, Pretoria, Unisa Press.

Lebakeng, J.T., Phalane, M.M. \& Dalindjebo, N., 2006, 'Epistemicide, institutional culture and the imperative for the Africanisation of Universities in South Africa, Alternation 13(1), 70-87.

LeBeau, D. \& Gordon, R., 2002, 'Challenges for anthropology in the African Renaissance: A Southern African contribution,' African Studies Review 47(1), 218-220.

Le Roux, A., 2001, 'African Renaissance: a quest for the transformation and Africanisation of South African education', South African Journal of Education 21(4), 31-36.

Letsekha, T., 2013, 'Revisiting the debate on the Africanisation of higher education: an appeal for a conceptual shift,' The Independent Journal of Teaching and Learning $8,5-7$.

Louw, D.J. \& Mouton, E., 2009, 'Die Fakulteit Teologie op die wipplanlk tussen verrassing en ontnugtering, waarheid en pyn', in P. Coertzen (red.), Teologie Stellenbosch 150+, bl. 53-72, Bybelmedia, Wellington.

Louw, W., 2010, 'Africanisation: A rich environment for active learning on a global platform,' Progressio 32(1), 42-54.

Maile, S., 2011, 'The absence of a home curriculum in post-apartheid education in South Africa', International Journal of African Renaissance Studies 6(2), 100-117. $\mathrm{http}: / / \mathrm{dx}$.doi.org/10.1080/18186874.2011.650852

Makgoba, M., 1997, Mokoko: The Makgoba affair - A reflection on transformation, Vivlia, Florida.

Makgoba, M. \& Seepe, S. 2004, 'Knowledge and Identity: An African Vision of higher education transformation', in S. Seepe (ed.), Towards an African identity of higher education, p. 1-44, Vista Úniversity, Pretoria.

Maluleke, T.S., 1996, 'Black and African theologies in the new world order: A time to drink from our own wells', Journal of Theology for Southern Africa 96, 3-19.

Maluleke, T.S., 1998, 'The Africanisation of theological education: Does theological education equip you to help your sister?', unpublished paper published in abridged form in Challenge 50 (Oct/Nov), 10-11.

Maluleke, T.S., 2000, 'The rediscovery of the agency of Africans', Journal of Theology for Southern Africa 104-108.

Maluleke, T.S., 2006, 'The Africanisation of theological education: Does theological education equip you to help your sister?', in E.P Antonio (ed.), Inculturation and postcolonial discourse in African Theology, pp. 46-55, Peter Laing Publishing, New York, NY.

Maluleke, T.S., 2010, 'Of Africanised bees and Africanised churches: Ten theses on African Christianity', Missionalia, Nov, 369-379.

Maweu, J.W., 2011, 'Indigenous ecological knowledge and modern Western ecological knowledge: Complimentary, not contradictory', Thought and Practice: A Journal of the Philosophical Association of Kenya 3(2), 35-47.

Mbiti, J., 1976, 'Theological impotence and the universality in the church', in G.H. Anderson \& T.F. Stransky (eds.), Mission trends no. 3: Third world theologies, Eerdmans, Grand Rapids, MI.

Mignolo, W.D., 2007, 'Delinking: The rhetoric of modernity, the logic of coloniality and the grammar of de-coloniality', Cultural Studies 21(2/3), 449-513. http://dx.doi. org/10.1080/09502380601162647

Mosala, I., 1985, 'African independent churches: A study in sociotheological protest,' in C. Villa-Vicencio \& J.W. De Gruchy (eds.), Resistance and hope. South African essays in honour of BeyersNaude, pp. 103-111, Eerdmans, Grand Rapids, MI.

Moulder, J., 1995, 'Universities and "Africanisation"' South African Journal of Higher Education 9(1), 7-8.

Neale-Shutte, M. \& Fourie, J., 2006, 'Challenges to internationalisation in African higher education' South African Journal of Higher Education 20(1), 118-142. http://dx.doi.org/10.4314/sajhe.v20i1.25562

Nehusi, K.S.K., 2004, 'Who is an African?', viewed 01 May 2015, from http://www. hollerafrica.com/pdf/vol1AfricanRenSep_Oct_2004.p df\#page $=18$

Nicolaides, A., 2012, 'Globalisation and Americanisation: The highjacking of indigenous African culture', Global Advanced Research Journal of History, Political Science and International Relations 1(6), 118-131.

Ntsimane, R., 2010, 'The fragile identity of being Lutheran and African: the vulnerability of confessional Lutheran seminaries in Africa today,' Studia Historiae Ecclesiasticae 36(2), 219-235. 
Nyamnjoh, F.B., 2004, 'A relevant education for African development - Some epistemological considerations', Africa Development-Senegal 29(1), 161-184.

Parker, B., 2003, 'Back on the Chain Gang: Some difficulties in developing a (South) African philosophy of education,' Journal of Education 30(1), 23-40.

Pityana, N.B., 2012, 'Higher education, transformation and Africanisation,' viewed 01 May 2015, from http://www.ieasa.studysa.org/resources/Study_SA/transformation Africanisation.pdf

Prah, K.K., 1998, In search for a tradition for social science research in Africa and vision for the 1990s, viewed 01 May 2015, from http://www.ossrea.net/eassrr/jan89/ kwesiprah

Ramose, M.B., 1997, Commentary on the green paper on higher education transformation, University of Venda, Venda.

Ramose, M.B., 1998, 'Foreword', in S. Seepe (ed.), Black perspectives on tertiary institutional transformation, Vivlia, Johannesburg.

Ramose, M.B., 2003, 'I doubt, therefore African philosophy exists', South African Journal of Philosophy 22(2), 110-121. http://dx.doi.org/10.4314/sajpem.v22i2.31364

Richardson, N. \& Leleki, S., 2010, 'From ecumenical experiment, to denominational necessity, to holistic vision: the Methodist journey in ministerial training, Missionalia 38(2), 235-247.

Robertson, R. \& Kathleen E.W., 2003. 'Globalization: An overview', in R. Robertson and K. E. White (eds.), Globalization: Critical concepts in sociology, vol. I, pp. 1-44, Routledge, London.

Sefa Dei, G.J., 2013, 'Learning culture, spirituality and local knowledge: Implication for African schooling', International Review of Education 48(5), 335-360. http:// dx.doi.org/10.1023/A:1021283730231
Shizha, E., 2011, 'Reclaiming our indigenous voices: The problem with the postcolonial sub-Saharan African school curriculum', Journal of Indigenous Social Development 2(1), 1-9.

Van Wyk, B. \& Higgs, P., 2005, 'Towards an African philosophy of higher education' South African Journal of Higher Education 18(3), 196-210. http://dx doi. org/10.4314/sajhe.v18i3.25491

Van Wyk, B. \& Higgs, P., 2011, 'The curriculum in an African context,' paper presented at the Comparative \& International Education Society (CIES) Conference, New York, 17-21 March.

Vorster, P.J. 1995, 'Africanisation: An explanation and some educational implications,' South African Journal of Education 15(1), 6-12.

Wa Thiong'o, N., 1987, Decolonising the mind: The politics of language in African literature, Zimbabwe Printing Press, Harare.

Wa Thiong'o, N., 1993, Moving the centre: The struggle for cultural freedoms, James Currey Ltd, London.

Williams, C. \& Gardner, J.C. 2012, 'Servant leadership, Africanization and disruptive innovation as conditions for effective leadership at UNISA', The Quarterly Review of Distance Education 13(4), 213-217.

Wiredu, K., 1995, 'Conceptual decolonisation in African philosophy,' in O. Oladipo (ed.), Selections and introductions: Conceptual decolonisation in African Philosophy - four essays, n.p., Hope Publications, Ibadan.

Wiredu, K., 2005, 'Philosophical considerations on the Africanisation of higher education in Africa', in Y. Waghid (ed.), African(a) philosophy of education: Reconstruction and deconstruction, pp. 6-18, Stellenbosch University, Matieland. 